\title{
Sandarakinorhabdus limnophila gen. nov., sp. nov., a novel bacteriochlorophyll a-containing, obligately aerobic bacterium isolated from freshwater lakes
}

\author{
Frederic Gich and Jörg Overmann
}

Correspondence

Jörg Overmann

j.overmann@Irz.uni-muenchen.de

\author{
Bereich Mikrobiologie, Ludwig-Maximilians-Universität München, Maria-Ward-Str. 1a, D-80638 \\ München, Germany
}

\begin{abstract}
Three strains (so36, so $42^{\top}$ and wo26) representing a novel Gram-negative, obligately aerobic, bacteriochlorophyll a-containing species of the $\alpha-4$ subgroup of the Proteobacteria were isolated from freshwater lakes using a high-throughput cultivation technique. The non-motile and slender rod-shaped cells formed orange-red-pigmented colonies. The main carotenoids were nostoxanthin and keto-nostoxanthin. According to the absorption spectrum, two different photosynthetic light-harvesting complexes, an LHI complex and a B800-830-type peripheral LHII complex, were present in the cells. The predominant fatty acids of strain so $42^{\top}$ were hexadecenoic acid $(16: 1 \omega 7 c)$ and octadecenoic acid $(18: 1 \omega 7 c)$, whereas $17: 1 \omega 6 c$ and $14: 0$ iso $2-\mathrm{OH}$ were present in smaller amounts. The main polar lipids were phosphatidylethanolamine, phosphatidylglycerol, phosphatidylcholine, diphosphatidylglycerol, glycolipid and sphingoglycolipids. The major respiratory lipoquinone was ubiquinone-10, whereas ubiquinone-9 was present in smaller amounts. The three strains were cytochrome oxidase-negative and catalase-positive and formed alkaline and acid phosphatases. The strains grew chemoorganoheterotrophically in mineral media supplemented with various organic acids, amino acids or complex substrates such as peptone and yeast extract. The $\mathrm{G}+\mathrm{C}$ content of the genomic DNA of strain so $42^{\top}$ was $64 \cdot 3 \mathrm{~mol} \%$. The three novel isolates contained the same 16S rRNA gene sequence. The 16S rRNA gene sequence similarity to the closest phylogenetic relative Sandaracinobacter sibiricus was only $92 \cdot 8 \%$. Accordingly, the three strains represent a new genus and species, for which the name Sandarakinorhabdus limnophila gen. nov., sp. nov., is proposed, with strain so $42^{\top}$ (=DSM $17366^{\top}=$ CECT $7086^{\top}$ ) as the designated type strain.
\end{abstract}

Aerobic, phototrophic, bacteriochlorophyll (BChl) acontaining bacteria have been isolated from a wide range of different environments and the spectrum of their ecological niches ranges from cryptoendolithic communities in Antarctica to symbiotic associations with microalgae (Yurkov \& Beatty, 1998; Allgaier et al., 2003; de la Torre et al., 2003). Despite their broad geographical distribution, the ecology and biogeochemical significance of aerobic, anoxygenic, phototrophic bacteria have only been studied in the marine environment, where they can constitute 10-30\% of the total bacterial community and account for up to $5 \%$ of the photosynthetic electron transport (Shiba et al., 1991;

Published online ahead of print on 16 December 2005 as DOI 10.1099/ijs.0.63970-0.

Abbreviations: $\mathrm{BChl}$ a, bacteriochlorophyll a; REP-PCR, repetitive extragenic palindromic DNA-PCR.

The GenBank/EMBL/DDBJ accession number for the 16S rRNA gene sequence of strain so $42^{\top}$ is $A Y 902680$.

A table detailing the substrate utilization patterns of strains so36, so $42^{\top}$ and wo26 is available as supplementary material in IJSEM Online.
Kolber et al., 2001; Béjà et al., 2002). In comparison, much less is known about the diversity and function of this bacterial group in freshwater lakes (Kolber et al., 2000; Page et al., 2004). Until very recently, freshwater representatives of aerobic, anoxygenic, phototrophic bacteria had been isolated exclusively from nutrient-rich sediment environments (Yurkov \& Beatty, 1998), such as cyanobacterial mats in warm or hot springs (Sandaracinobacter, Erythromonas, Erythromicrobium, Roseococcus and Porphyrobacter) or from the surfaces of subtropical ponds (Porphyrobacter), river water (Roseateles) and acidic mineral environments and mine drainages (Acidiphilium and Acidisphaera). All planktonic species of marine and freshwater, aerobic, phototrophic bacteria isolated to date are affiliated with either the Rhodobacteraceae ( $\alpha-3$ subgroup of the Proteobacteria) or the $\beta-1$ subgroup of the Proteobacteria (Yurkov, 2001). Very recently, however, two planktonic BChl $a$-containing species (Rhodobacter sp. HTCC515 and the betaproteobacterium HTCC528) were isolated from the ultraoligotrophic Crater Lake, OR, USA (Page et al., 2004). Freshwater environments may therefore harbour a greater diversity and abundance of 
aerobic, anoxygenic, phototrophic bacteria than that appreciated to date.

In the present study, we describe the first phototrophic, planktonic freshwater species representing a novel lineage within the $\alpha-4$ subgroup of the Proteobacteria to be isolated in pure culture. The novel phylotype was also detected in situ by PCR-denaturing gradient gel electrophoresis fingerprinting in a previous study (Gich et al., 2005). Dot-blot hybridization with genomic probes demonstrated that the isolates constitute $0 \cdot 5-2 \cdot 3 \%$ of the natural bacterioplankton community (Gich et al., 2005). Furthermore, the $16 \mathrm{~S}$ rRNA gene sequence of the isolates was detected in lakes of all trophic states (oligotrophic to eutrophic) (Gich et al., 2005). The novel type of bacterium thus appears to represent a typical and widely distributed constituent of freshwater bacterioplankton. Future studies will reveal whether aerobic, anoxygenic, phototrophic bacteria of the $\alpha 4$-subgroup of the Proteobacteria are of significance for the carbon cycle in freshwater lakes.

Bacterial strains were isolated from the mesotrophic prealpine Starnberger See $(25 \mathrm{~km}$ south-west of Munich, Germany) and from the oligotrophic alpine Walchensee (near Garmisch-Partenkirchen, $50 \mathrm{~km}$ south of Munich), as described previously (Bruns et al., 2003; Gich et al., 2005). Purification of the colonies was performed on agar plates containing synthetic freshwater medium and a ten-vitamin mixture (Bartscht et al., 1999) and 1\% (w/v) peptone. Cell morphology was examined by using an inverse phasecontrast microscope (Axiovert 200; Zeiss). The three isolates grew as single cells and formed orange-red-pigmented colonies with a smooth surface on synthetic freshwater agar medium. Colonies of strain so42 ${ }^{\mathrm{T}}$ were bigger $(1-3 \mathrm{~mm})$ than those of strains so36 and wo 26 (usually $\leqslant 0.5 \mathrm{~mm}$ ). In addition, the colonies of strain so $42^{\mathrm{T}}$ had a mucilaginous texture because of the production of extracellular slime. The strains could be stored at $-80{ }^{\circ} \mathrm{C}$ in $50 \%$ glycerol or $7 \%$ DMSO for at least 7 months. The cells were non-motile rods and reproduced by binary fission (Fig. 1a). During exponential growth, cells were $0.32 \pm 0 \cdot 09 \times 1 \cdot 55 \pm 0 \cdot 44 \mu \mathrm{m}$ (strain so36), $0 \cdot 31 \pm 0 \cdot 06 \times 0 \cdot 80 \pm 0 \cdot 19 \mu \mathrm{m}\left(\right.$ strain so $\left.42^{\mathrm{T}}\right)$ and $0 \cdot 26 \pm 0 \cdot 05 \times 2 \cdot 33 \pm 0 \cdot 83 \mu \mathrm{m}$ (strain wo26) (Table 1). Cells of strain so $42^{\mathrm{T}}$ elongated upon entry into the stationary phase (Fig. 1b), becoming $0 \cdot 24 \pm 0 \cdot 03 \times 3 \cdot 24 \pm 0 \cdot 81 \mu \mathrm{m}$. No change in cell volume occurred upon transfer of cultures from low-nutrient artificial freshwater medium to media containing high concentrations of complex substrates. Electron microscopy of ultrathin sections indicated that the cells possessed a typical Gram-negative cell wall (Fig. 1c). No intracytoplasmic membrane systems were detected. Many cells contained a single electron-dense polar granule, most probably consisting of polyphosphate.

Absorption spectra were monitored with a Lambda $25 \mathrm{UV} /$ VIS spectrophotometer (Perkin Elmer). Absorption spectra of whole cells in sucrose (Fig. 2) were similar for all three strains and exhibited maxima at 430-490 and 800-865 nm, indicating the presence of carotenoids and BChl $a$,
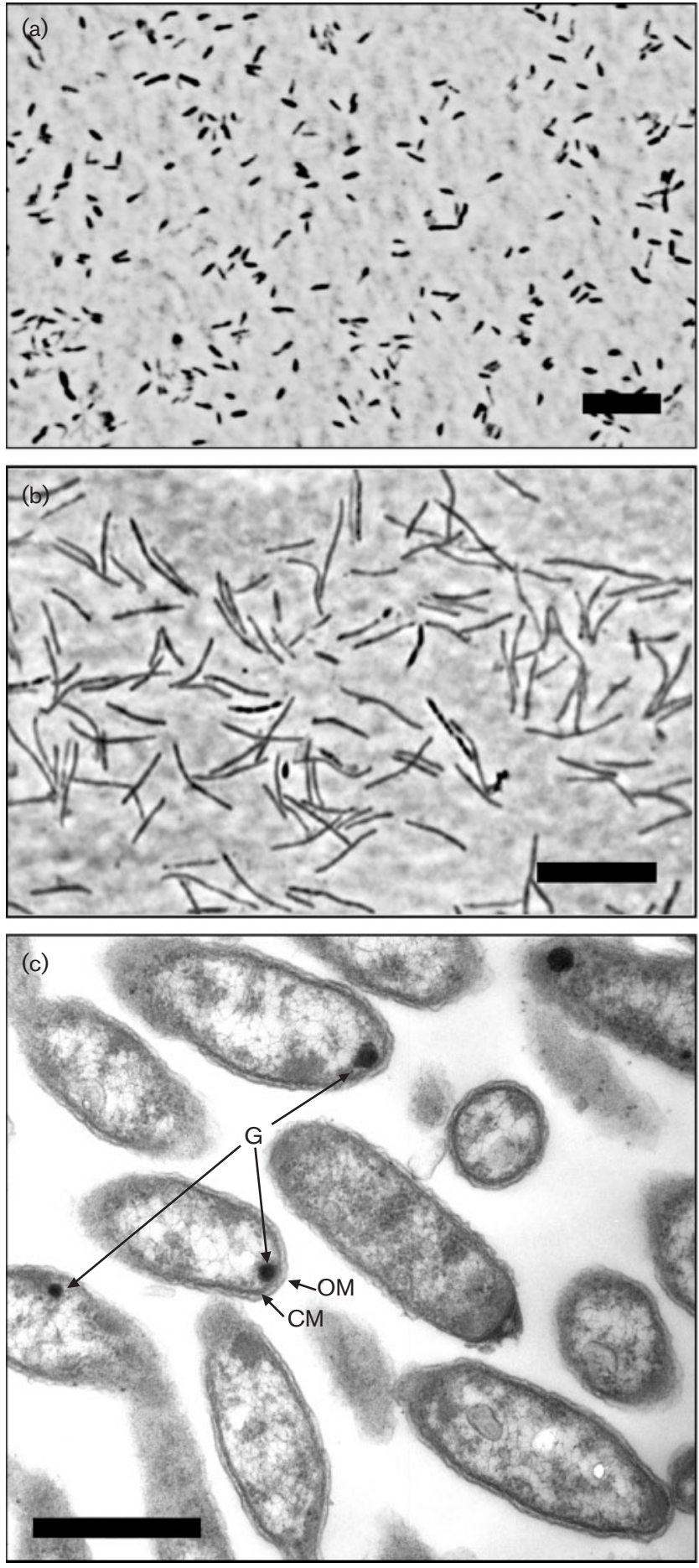

Fig. 1. Phase-contrast photomicrographs of cells of isolate so $42^{\top}$ during exponential growth (a) and in stationary phase (b). (c) Ultrathin section of exponentially grown cells of strain so $42^{\top}$ stained with $1 \%$ uranyl acetate. The outer membrane (OM), cytoplasmic membrane (CM) and intracellular granules $(\mathrm{G})$ can be distinguished. Bars, $5 \mu \mathrm{m}(\mathrm{a}, \mathrm{b})$ and $0.5 \mu \mathrm{m}$ (c).

respectively. Absorption maxima at 800 and $865 \mathrm{~nm}$ and the shoulder at $837 \mathrm{~nm}$ (Fig. 2b) are characteristic for two 
Table 1. Main morphological, biochemical and physiological characteristics of the three isolates of Sandarakinorhabdus limnophila gen. nov., sp. nov., compared with Sandaracinobacter sibiricus RB16-17 ${ }^{\top}$

Data for Sandaracinobacter sibiricus taken from Yurkov \& Gorlenko (1990). ND, Not determined. All strains were isolated from a freshwater environment and are Gram-negative with rod-shaped cells. No information on enzymic activities (other than those involved in glycolysis and the tricarboxylic acid cycle), polar lipids or fatty acid composition is available for Sandaracinobacter sibiricus RB16-17 ${ }^{\mathrm{T}}$.

\begin{tabular}{|c|c|c|c|c|}
\hline Characteristic & so36 & so $42^{\mathrm{T}}$ & wo26 & $\begin{array}{l}\text { Sandaracinobacter } \\
\text { sibiricus } \mathrm{RB} 16-17^{\mathrm{T}}\end{array}$ \\
\hline Environment & Planktonic & Planktonic & Planktonic & Benthic \\
\hline Width $(\mu \mathrm{m})$ & $0 \cdot 32 \pm 0 \cdot 09$ & $0 \cdot 31 \pm 0 \cdot 06$ & $0 \cdot 26 \pm 0 \cdot 05$ & $0 \cdot 3-0 \cdot 5$ \\
\hline Length $(\mu \mathrm{m})$ & $1 \cdot 55 \pm 0 \cdot 44$ & $0 \cdot 80 \pm 0 \cdot 19$ & $2 \cdot 33 \pm 0 \cdot 83$ & $1 \cdot 5-2 \cdot 5$ \\
\hline Volume $\left(\mu \mathrm{m}^{3}\right)$ & $0 \cdot 15 \pm 0 \cdot 09$ & $0.08 \pm 0.05$ & $0 \cdot 14 \pm 0 \cdot 06$ & ND \\
\hline Motility & - & - & - & + (3 subpolar flagella) \\
\hline Colour & Orange-red & Orange-red & Orange-red & Yellow-orange \\
\hline Cytochrome oxidase & - & - & - & + \\
\hline Catalase & + & + & + & - \\
\hline $\begin{array}{l}\text { In vivo absorption maxima of } \\
\text { carotenoids }(\mathrm{nm})\end{array}$ & $420,460,480$ & $420,460,480$ & $420,460,480$ & $424,450,474$ \\
\hline LHI (nm) & 865 & 865 & 865 & 867 \\
\hline LHII (nm) & 800,837 (shoulder) & 800,837 (shoulder) & 800,837 (shoulder) & - \\
\hline Quinone & ND & $\begin{array}{c}\text { Ubiquinone-9 }(8 \%) \text {, } \\
\text { ubiquinone-10 }(92 \%)\end{array}$ & ND & $\begin{array}{l}\text { Ubiquinone- } 9 \text {, } \\
\text { ubiquinone-10 }\end{array}$ \\
\hline Main polar lipids* & ND & $\begin{array}{l}\text { DPG, PG, PE, } \\
\text { PC, SGL, GL }\end{array}$ & $\mathrm{ND}$ & ND \\
\hline DNA G $+C$ content $(\mathrm{mol} \%)$ & $\mathrm{ND}$ & $64 \cdot 3$ & $\mathrm{ND}$ & $68 \cdot 5$ \\
\hline Metabolism & Strictly aerobic & Strictly aerobic & Strictly aerobic & $\begin{array}{c}\text { Strictly aerobic } \\
\text { (facultative } \\
\text { photoheterotroph) }\end{array}$ \\
\hline Peptone, optimum $(\%, \mathrm{w} / \mathrm{v})$ & $0 \cdot 1$ & $1 \cdot 0$ & $1 \cdot 0$ & $\mathrm{ND}$ \\
\hline Butyrate $(2 \cdot 5 / 9 \mathrm{mM})$ & - & + & + & + \\
\hline Succinate $(10 / 4 \mathrm{mM})$ & - & + & - & - \\
\hline Lactate $(10 / 9 \mathrm{mM})$ & - & + & - & - \\
\hline Fumarate $(5 / 6 \mathrm{mM})$ & + & - & - & - \\
\hline Methanol $(5 / 31 \mathrm{mM})$ & - & - & + & - \\
\hline
\end{tabular}

${ }^{*}$ DPG, Diphosphatidylglycerol; GL, glycolipid; PC, phosphatidylcholine; PE, phosphatidylethanolamine; PG, phosphatidylglycerol; SGL, sphingoglycolipids.

$\dagger$ Concentrations used for the substrate test: isolates/Sandaracinobacter sibiricus.

different photosynthetic, light-harvesting complexes, LHI $(865 \mathrm{~nm})$ and a B800-830-type LHII $(800-837 \mathrm{~nm})$. LHII is present in only a few and very distantly related aerobic phototrophic bacteria, namely Erythromicrobium ramosum, 'Erythromicrobium ezovicum' and 'Erythromicrobium hydrolyticum', and is missing from Sandaracinobacter sibiricus and other species (Yurkov et al., 1997; Yurkov \& Beatty, 1998). Because the novel type of bacterium was found in lakes of all trophic states, the presence of a photosynthetic apparatus is not simply an adaptation to oligotrophic environments. This is supported by the observation that the isolates grew in mineral media supplemented with up to $1 \%$ peptone and 
(a)

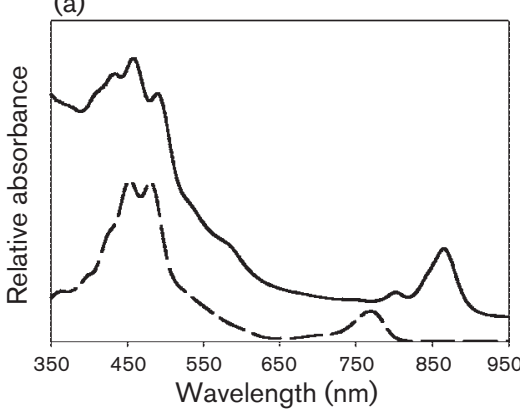

(b)

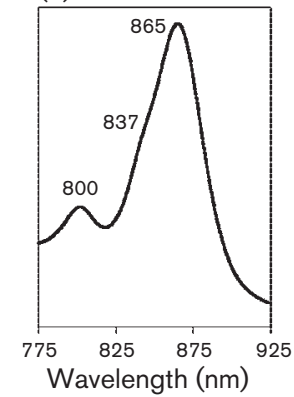

Fig. 2. (a) Absorption spectra of whole cells in $60 \%$ sucrose (solid line) and acetone extracts (dashed line) of isolate so $42^{\top}$. (b) Detail of long-wavelength absorption maxima of the photosynthetic, light-harvesting complexes LHI $(865 \mathrm{~nm})$ and LHII (at $800 \mathrm{~nm}$ and shoulder at $837 \mathrm{~nm}$ ).

hence are not obligate oligotrophs. Carotenoid analysis was performed by HPLC according to method B of Airs et al. (2001). Individual carotenoids were identified according to their retention time and absorption spectra by cochromatography of pigment extracts of the reference strains Erythrobacter longus DSM $6997^{\mathrm{T}}$ and Erythromicrobium ramosum DSM $8510^{\mathrm{T}}$. The strains contained $\mathrm{BChl} a$ esterified with phytol (BChl $a_{\mathrm{P}}$ ). Based on HPLC analyses, three major carotenoids were present. All three strains contained nostoxanthin as a major carotenoid. Strains so36 and wo26 had an almost identical pigment composition and contained keto-nostoxanthin as a second major carotenoid. In addition, the three strains contained two unidentified carotenoids that are novel among the aerobic, anoxygenic phototrophic bacteria, an unidentified carotenoid containing a keto group $\left(\lambda_{\max }=590 \mathrm{~nm}\right)$ resembling bacteriorubixanthinal and a cis-isomer of this unidentified carotenoid.

Results of the chemotaxonomic analyses are given in the species description. The following analytical procedures were performed. Respiratory lipoquinones and polar lipids were extracted from 2 and $0 \cdot 1 \mathrm{~g}$, respectively, freeze-dried cell material and analysed according to Tindall (1990a, b). Polar lipid analyses were carried out by the Identification Services and B. J. Tindall, DSMZ. For fatty acid analysis, $40 \mathrm{mg}$ (wet weight) of cells was scraped from Petri dishes and the fatty acid methyl esters were extracted by using the method of Miller (1982) and Kuykendall et al. (1988). DNA $\mathrm{G}+\mathrm{C}$ content was analysed according to Mesbah et al. (1989). The polar lipid fingerprints of the isolates so36, so $42^{\mathrm{T}}$ and wo 26 obtained by two-dimensional TLC were similar to those of Sphingomonas phyllosphaerae $\mathrm{FA} 2^{\mathrm{T}}$ (Rivas et al., 2004) and were identified by their chromatographic behaviour and staining characteristics (Fig. 3). The fatty acid composition is summarized in Table 2. Interestingly, only one saturated fatty acid without hydroxy groups was detected in strain so $42^{\mathrm{T}}(16: 0)$, whereas a variety of saturated fatty acids are commonly found in the alphaproteobacteria

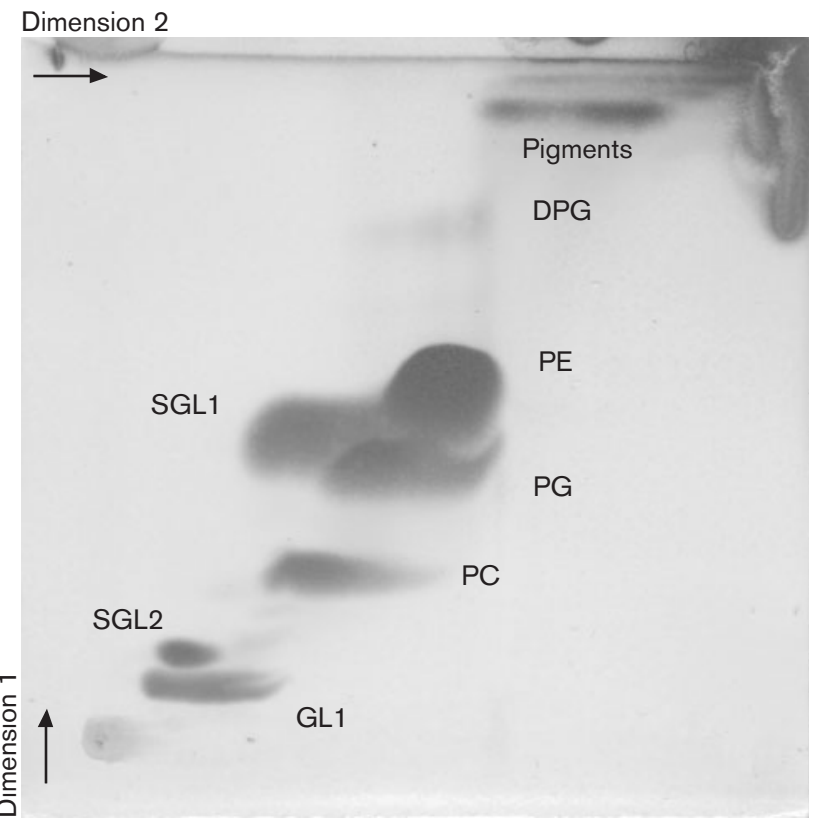

Fig. 3. Polar lipids of strain so $42^{\top}$ after separation by twodimensional TLC. DPG, Diphosphatidylglycerol; GL1, glycolipid; PC, phosphatidylcholine; PE, phosphatidylethanolamine; PG, phosphatidylglycerol; SGL1 and SGL2, sphingoglycolipids. Digital image courtesy of B. J. Tindall (DSMZ).The first dimension was developed in chloroform/methanol/water $(65: 25: 4$, by vol.) and the second dimension in chloroform/methanol/acetic $\mathrm{acid} /$ water ( $80: 12: 15: 4$, by vol.).

(Denner et al., 2002; Rainey et al., 2003; Yoon et al., 2003, 2004). The similarity index of the fatty acid patterns of strain so $42^{\mathrm{T}}$ and the closest related species present in the MIDI database, Novosphingobium aromaticivorans $\mathrm{F} 199^{\mathrm{T}}$, was $0 \cdot 04$. Since a similarity value of $>0.30$ is indicative of strains belonging to the same species, the fatty acid analyses provide independent evidence for an isolated phylogenetic position of the three strains.

Gram-staining and catalase and oxidase tests were performed by using conventional methods (Gerhardt, 1994). Strains so 36, so $42^{\mathrm{T}}$ and wo 26 were Gram-negative and tested negative for cytochrome oxidase and were catalase-positive. Enzymic activities were determined with the API ZYM test system (bioMérieux), according to the manufacturer's protocol. The three isolates produced the same spectrum of enzyme activities (Table 3 ) except for trypsin and $\beta$ galactosidase, which were only detected as weak activities in the isolates so $42^{\mathrm{T}}$ and wo26, respectively. The three isolates showed a strong positive reaction in tests for alkaline and acid phosphatases, which is consistent with an adaptation to limiting phosphate concentrations in Walchensee and Starnberger See (Chróst, 1991; Gich et al., 2005).

The strains were characterized further by using aerobic growth tests in microtitre plates using synthetic freshwater medium supplemented with 69 individual carbon substrates 
Table 2. Cellular fatty acid composition (\%) of isolate so42 ${ }^{\top}, \quad$ N. aromaticivorans $\mathrm{F} 199^{\top}$, Erythrobacter citreus DSM $14432^{\top}$, Erythromicrobium ramosum DSM $8510^{\top}$, Roseisalinus antarcticus DSM $11466^{\top}$ and Porphyrobacter cryptus DSM $12079^{\top}$

Strains: 1 , so $42^{\mathrm{T}} ; 2$, N. aromaticivorans $\mathrm{F} 199^{\mathrm{T}}$ (data from MIDI database); 3, Erythrobacter citreus DSM $14432^{\mathrm{T}}$ (Denner et al., 2002); 4, Erythromicrobium ramosum DSM $8510^{\mathrm{T}}$ (Denner et al., 2002); 5, Roseisalinus antarcticus DSM $11466^{\mathrm{T}}$ (Labrenz et al., 2005); 6, P. cryptus DSM $12079^{\mathrm{T}}$ (Rainey et al., 2003). -, Not detected.

\begin{tabular}{|lcccccc|}
\hline Compound & $\mathbf{1}$ & $\mathbf{2}$ & $\mathbf{3}$ & $\mathbf{4}$ & $\mathbf{5}$ & $\mathbf{6}$ \\
\hline Saturated fatty acids & & & & & & \\
$16: 0$ & $6 \cdot 99$ & $3 \cdot 3$ & $8 \cdot 2$ & $3 \cdot 0$ & $15 \cdot 1$ & $5 \cdot 0$ \\
Unsaturated fatty acids & & & & & & \\
$16: 1 \omega 5 c$ & $2 \cdot 33$ & $0 \cdot 3$ & $3 \cdot 6$ & - & - & - \\
$16: 1 \omega 7 c$ & $35 \cdot 07$ & $2 \cdot 8$ & - & - & $2 \cdot 1$ & $1 \cdot 2$ \\
$17: 1 \omega 6 c$ & $6 \cdot 12$ & $1 \cdot 1$ & $5 \cdot 6$ & $39 \cdot 7$ & - & $21 \cdot 1$ \\
$18: 1 \omega 7 c$ & $33 \cdot 58$ & $38 \cdot 0$ & $49 \cdot 3$ & $45 \cdot 9$ & $62 \cdot 0$ & - \\
Hydroxy fatty acids & & & & & & \\
$14: 0$ iso 2-OH & $9 \cdot 32$ & $26 \cdot 7$ & $0 \cdot 9$ & - & - & $4 \cdot 7$ \\
$15: 0$ 2-OH & $1 \cdot 39$ & $2 \cdot 2$ & - & $2 \cdot 7$ & - & $7 \cdot 4$ \\
$16: 0$ iso 3-OH & $1 \cdot 64$ & - & $1 \cdot 0$ & - & - & - \\
$16: 0$ 2-OH & $3 \cdot 56$ & $1 \cdot 1$ & - & - & - & - \\
Summed feature & & & & & & \\
1 & $35 \cdot 07$ & - & $14 \cdot 9$ & $3 \cdot 5$ & - & - \\
2 & - & - & $1 \cdot 3$ & - & - & - \\
\hline
\end{tabular}

${ }^{\star}$ Summed features represent a group of fatty acids that could not be separated by GLC with the MIDI system. Summed feature 1 contained $16: 1 \omega 7 c$ and/or $15: 0$ iso $2-\mathrm{OH}$. Feature 2 contained $18: 2 \omega 6,9 c, 18: 0$ anteiso and/or $18: 2 \omega 6,9 c$.

in two parallels. Negative controls devoid of substrates or without inoculum were used throughout. After incubation for 8 weeks in the dark at $15^{\circ} \mathrm{C}$, substrate utilization was assessed by measuring the optical density at $620 \mathrm{~nm}$ in each well using a microtitre plate reader (TECAN Sunrise Remote Control). Fermentative metabolism and anaerobic respiration with nitrate or sulfate were studied using standard anaerobic culturing techniques (Miller \& Wolin, 1974). The isolates grew as obligately aerobic chemoorganoheterotrophs. Fermentation or anaerobic growth with nitrate or sulfate were not detected. However, the three strains differed with respect to carbon utilization (see Supplementary Table S1 in IJSEM Online). Since our strains were isolated from oligotrophic freshwater lakes with low organic carbon content, two concentrations of fatty acids and complex substrates were tested with respect to possible inhibition of growth. All three strains grew readily with crotonate, protocatechuate and valerate, but did not utilize most alcohols (nine of ten) or sugars (29 of 31) tested. The only commonly used sugar and amino acid in all three strains were glucose and $(+)-\mathrm{L}-$ cysteine, respectively. Strain so36 did not use any of the tested oxo-acids. All three strains were capable of growing
Table 3. Enzymes detected in strains so36, so42 ${ }^{\top}$ and wo26

Results of API ZYM tests. +++ , Very strong positive reaction; ++ , strong positive reaction; + , weakly positive reaction. The following tests were negative for all strains: lipase (C14), $\alpha$-galactosidase, $\beta$-glucuronidase, $\alpha$-glucosidase, $\beta$-glucosidase, $N$-acetyl- $\beta$ glucosaminidase, $\alpha$-mannosidase, $\alpha$-fucosidase.

\begin{tabular}{|lccc|}
\hline Enzyme assay & so36 & so42 $^{\mathbf{T}}$ & wo26 \\
\hline Alkaline phosphatase & +++ & +++ & +++ \\
Esterase (C4) & + & + & + \\
Esterase lipase (C8) & + & + & + \\
Leucine arylamidase & +++ & +++ & +++ \\
Valine arylamidase & + & ++ & + \\
Cystine arylamidase & + & + & + \\
$\alpha$-Chymotrypsin & + & ++ & + \\
Acid phosphatase & +++ & +++ & ++ \\
Naphthol-AS-BI-phosphohydrolase & ++ & ++ & ++ \\
\hline
\end{tabular}

on complex organic substrates such as Casamino acids, yeast extract and peptone, but no growth was observed when fermented rumen extract was used, even at low concentrations $(0 \cdot 001 \%)$. Maximum growth rates were achieved for all three strains at $0 \cdot 1 \%$ [460 $\left.(\mathrm{mg} \mathrm{C}) 1^{-1}\right]$ yeast extract. Strains so $42^{\mathrm{T}}$ and wo 26 showed a higher tolerance towards peptone [maximum growth rates observed at $1 \%$ peptone, corresponding to $4 \cdot 3 \mathrm{~g}(\mathrm{mg} \mathrm{C}) \mathrm{l}^{-1}$, whereas the maximum growth rate of strain so36 was observed at $0 \cdot 1 \%$ peptone $\left[0 \cdot 4(\mathrm{~g} \mathrm{C}) 1^{-1}\right]$. The minimum doubling times recorded for the strains were between $12 \cdot 1$ and $16 \cdot 8 \mathrm{~h}$. When precultures grown at low substrate concentrations were inoculated into these complex media with high substrate concentrations, lag phases of up to $80 \mathrm{~h}$ occurred.

The 16S rRNA genes were amplified for each of the three strains using primers $8 \mathrm{f}$ and 1492r (Lane, 1991). The PCR products were separated from free PCR primers, purified using the QIAquick Spin kit (Qiagen) and sequenced directly employing eight primers to cover the entire 16S rRNA gene (Gich et al., 2005), using an ABI Prism BigDye Terminator cycle sequencing ready reaction kit (Applied Biosystems) and an ABI Prism 310 Genetic Analyzer (Applied Biosystems). Sequences were analysed using the ARB software package (Ludwig et al., 2004). Additional sequences of close relatives of other more recently described BChl $a$-containing alphaproteobacteria present in GenBank were retrieved from the database employing BLAST 2.0.4 (Altschul et al., 1997) and imported into the ARB database. The Fast Aligner V1.03 tool was used for automatic sequence alignment with previously aligned sequences from the ARB database. The alignment was subsequently checked and corrected manually based on secondary-structure information. Phylogenetic trees were constructed using maximumlikelihood and neighbour-joining methods and bootstrap values were calculated to determine the robustness of the clusters. Sequence similarities were calculated using the ARB 
distance matrix. A comparison of the almost-complete $16 \mathrm{~S}$ rRNA gene sequences (positions 60-1458, Escherichia coli numbering) revealed that all three isolates contained identical sequences. Maximum-likelihood and neighbour-joining analyses led to the same results (Fig. 4). Based on the phylogenetic analysis, the isolates belong to the family Sphingomonadaceae, with Sandaracinobacter sibiricus strain RB16-17 ${ }^{\mathrm{T}}$, an aerobic BChl $a$-containing bacterium that forms an isolated phylogenetic branch among non-photosynthetic members of the $\alpha-4$ subgroup of the Proteobacteria, representing the most closely related species with a validly published name. The latter was isolated from a microbial mat in freshwater near hydrothermal sulfide-containing vents on the bottom of the Bol'shoi river (Yurkov \& Gorlenko, 1990). The sequence similarity of isolates so36, so $42^{\mathrm{T}}$ and wo 26 to Sandaracinobacter sibiricus was $92 \cdot 8 \%$, which clearly indicates an independent phylogenetic lineage. A $16 \mathrm{~S}$ rRNA gene sequence divergence of $3 \%$ is commonly used as a criterion for the separation of two bacterial species (Stackebrandt \& Goebel, 1994). Bacterial genera typically show $\leqslant 93 \%$ sequence similarity of the 16S rRNA gene. Numerous cytological, biochemical and physiological characteristics (Table 1) support the conclusion that the three isolates represent a novel bacterial genus. Accordingly, a new genus and species, Sandarakinorhabdus limnophila gen. nov., sp. nov., is proposed. Genomic fingerprints generated with ERIC-PCR or repetitive extragenic palindromic DNA (REP)-PCR primers (de Bruijn, 1992) ranged from 6000 to 400 bp (Fig. 5). According to both analyses, strains so 36 and wo26 are more similar to each other than to strain so $42^{\mathrm{T}}$.

\section{Description of Sandarakinorhabdus gen. nov.}

Sandarakinorhabdus (San.da.ra'ki.no.rhab'dus. Gr. adj. sandarakinos of orange colour; Gr. fem. n. rhabdos rod; N.L. fem. n. Sandarakinorhabdus orange-coloured rod).

Cells are non-spore-forming, non-motile rods that do not form a capsule and are Gram-negative. They reproduce by binary fission and form orange-red-pigmented colonies with smooth surfaces on agar plates. Cells may contain polyphosphate granules and exhibit strong enzymic activity for acid and alkaline phosphatases. Cytochrome oxidase-negative and catalase-positive. Obligately aerobic chemoorganoheterotrophs. Fermentation or anaerobic growth with nitrate or sulfate are not detected. Produce Bchl $a$. Grow in the presence of a number of short-chain organic acids and amino acids as electron donors and carbon sources. Grow well in media containing $0 \cdot 1 \%$ peptone or yeast extract. $16 \mathrm{~S}$ rRNA gene sequence information places the genus within the $\alpha-4$ subgroup of the Proteobacteria, with Sandaracinobacter as its phylogenetic neighbour. The type species is Sandarakinorhabdus limnophila.
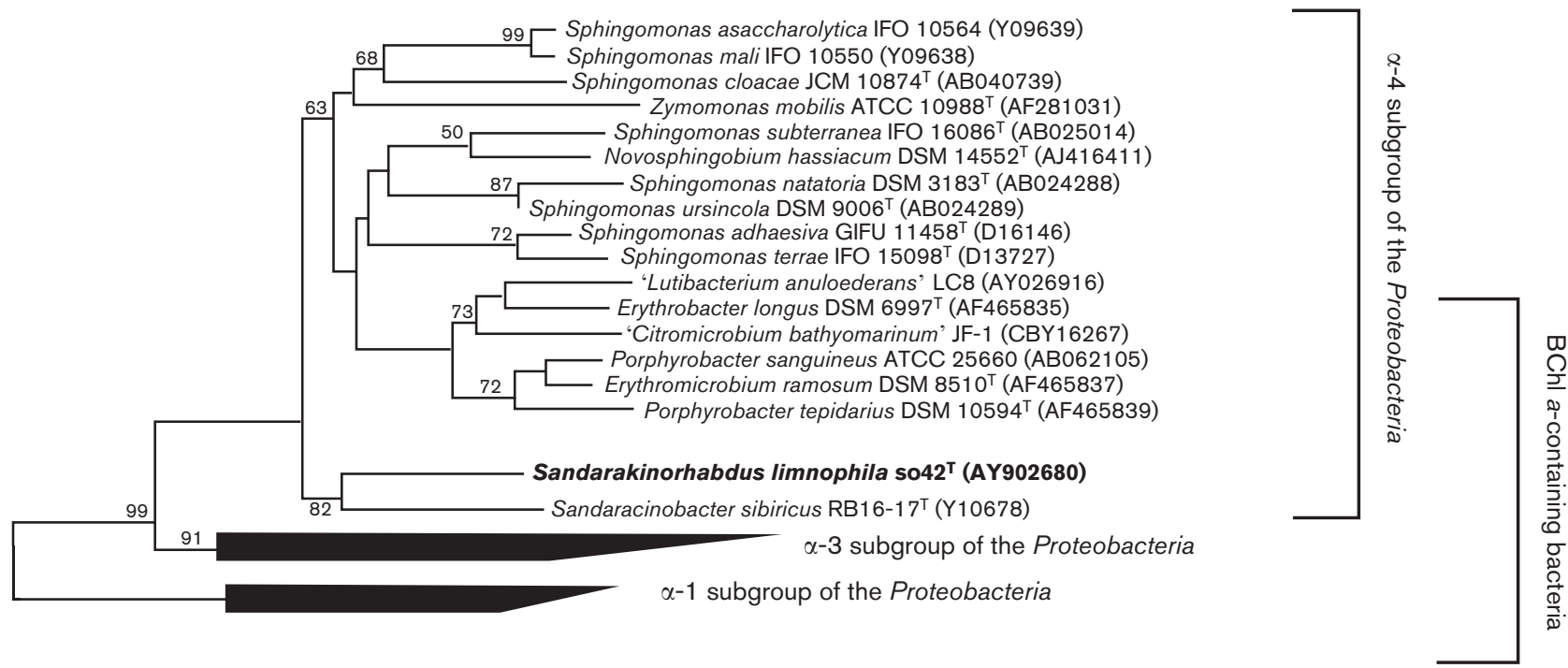

Fig. 4. Maximum-likelihood phylogenetic tree calculated from $16 \mathrm{~S}$ rRNA gene sequences of the three isolates and aerobic phototrophic members of the $\alpha-1, \alpha-3$ and $\alpha-4$ subgroups of the Proteobacteria and the closely related genus Sphingomonas. Bar, 10 nucleotide substitutions per 100 nucleotides. Bootstrap values were calculated from 1000 bootstrap resamplings; only values $\geqslant 50 \%$ are depicted. Sequences included in cluster $\alpha-1$ subgroup of the Proteobacteria were Craurococcus roseus NS130 ${ }^{\top}$ (D85828), Paracraurococcus ruber NS89 ${ }^{\top}$ (D85827), Roseococcus thiosulfatophilus RB3 ${ }^{\top}$ (X72908), Acidiphilium rubrum ATCC $35905^{\top}$ (D30776) and Acidisphaera rubrifaciens HS-AP3 ${ }^{\top}$ (D86512). Sequences included in cluster $\alpha-3$ subgroup of the Proteobacteria were Roseobacter denitrificans DSM $7001^{\top}$ (AJ012706), Roseovarius tolerans EL-172 ${ }^{\top}$ (Y11551), Roseivivax halotolerans Och $210^{\top}$ (D85831) and Rubrimonas cliftonensis OCh $317^{\top}$ (D85834). Roseateles depolymerans $61 \mathrm{~A}^{\top}$ (AB208738) was used as the outgroup (not shown). 


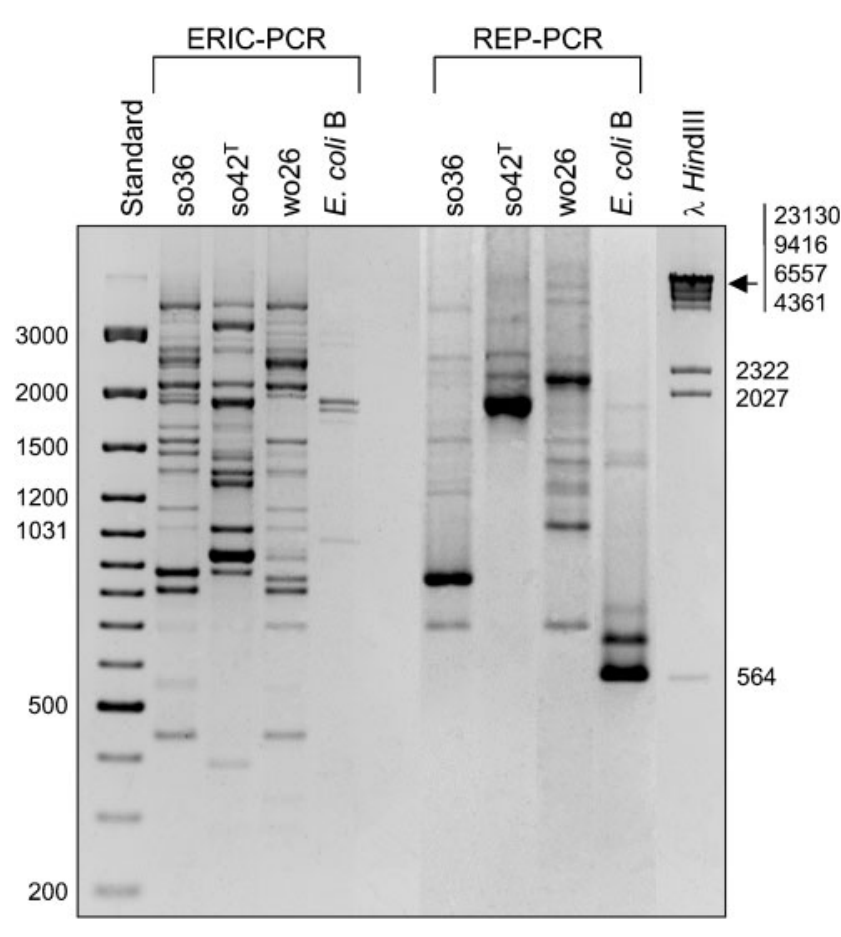

Fig. 5. Negative image of an ethidium bromide-stained agarose gel showing ERIC-PCR and REP-PCR fingerprint patterns generated for strains so36, so $42^{\top}$ and wo26. Two different DNA molecular size standards (bp) are also shown. E. coli strain B was used as a control.

\section{Description of Sandarakinorhabdus limnophila sp. nov.}

Sandarakinorhabdus limnophila [lim.no' phi.la. Gr. n. limnos (or limnè) lake, pool of standing water; Gr. adj. philos loving; N.L. fem. adj. limnophila lake-loving, isolated from a freshwater lake].

General characteristics are the same as those given in the description of the genus. Rods are $0 \cdot 31 \pm 0 \cdot 06 \times 0 \cdot 80 \pm$ $0 \cdot 19 \mu \mathrm{m}$ with a biovolume of $0 \cdot 08 \mu \mathrm{m}^{3}$. Facultatively oligotrophic, grows as single cells and forms orange-red colonies of 1-3 mm with mucilaginous texture on agar plates. Cells absorb at $430-490 \mathrm{~nm}$ and at 800,837 and $865 \mathrm{~nm}$, because of the presence of carotenoids and $\mathrm{BChl} a_{\mathrm{P}}$, respectively. Nostoxanthin is the main carotenoid. In addition, two unidentified carotenoids containing keto groups are present. Keto-nostoxanthin may also be present in some strains. Contains two different light-harvesting complexes (LHI and LHII). Grows well in media containing up to $1 \%$ peptone. Major fatty acids of the cellular lipids are hexadecenoic acid $(16: 1 \omega 7 c)$ and octadecenoic acid $(18: 1 \omega 7 c)$. Predominant glycolipids are phosphatidylethanolamine, phosphatidylglycerol, phosphatidylcholine, diphosphatidylglycerol, glycolipid and two sphingoglycolipids. The respiratory lipoquinones are ubiquinone-10 (92\%) and ubiquinone-9 $(8 \%)$. The $\mathrm{G}+\mathrm{C}$ content of the genomic DNA is $64 \cdot 3 \mathrm{~mol} \%$ (determined by HPLC).
The type strain is $\operatorname{so} 42^{\mathrm{T}}\left(=\mathrm{DSM} 17366^{\mathrm{T}}=\mathrm{CECT} 7086^{\mathrm{T}}\right)$, which was isolated from the mesotrophic freshwater lake Starnberger See (Bavaria, Germany).

\section{Acknowledgements}

We thank Karin Schubert for assistance with the pigment analysis by HPLC. Gerhard Wanner (Bereich Botanik, Ludwig-MaximiliansUniversität, München, Germany) is acknowledged for help with transmission electron microscopy images. We are indebted to AnnKatrin Manske for assistance with the phylogenetic analyses. This work was funded by the BMBF (Bundesministerium für Bildung, Wissenschaft, Forschung und Technologie) to J.O. (grant no. BIOLOG/01LC0021).

\section{References}

Airs, R. L., Atkinson, J. E. \& Keely, B. J. (2001). Development and application of a high resolution liquid chromatographic method for the analysis of complex pigment distributions. J Chromatogr A 917, 167-177.

Allgaier, M., Uphoff, H., Felske, A. \& Wagner-Döbler, I. (2003). Aerobic anoxygenic photosynthesis in Roseobacter clade bacteria from diverse marine habitats. Appl Environ Microbiol 69, 5051-5059.

Altschul, S. F., Madden, T. L., Schäffer, A. A., Zhang, J., Miller, W. \& Lipman, D. J. (1997). Gapped BLAST and PSI-BLAST: a new generation of protein database search programs. Nucleic Acids Res 25, 3389-3402.

Bartscht, K., Cypionka, H. \& Overmann, J. (1999). Evaluation of cell activity and of methods for the cultivation of bacteria from a natural lake community. FEMS Microbiol Ecol 28, 249-259.

Bèjà, O., Suzuki, M. T., Heidelberg, J. F., Nelson, W. C., Preston, C. M., Hamada, T., Eisen, J. A., Fraser, C. M. \& DeLong, E. F. (2002). Unsuspected diversity among marine aerobic anoxygenic phototrophs. Nature 415, 630-633.

Bruns, A., Hoffelner, H. \& Overmann, J. (2003). A novel approach for high throughput cultivation assays and the isolation of planktonic bacteria. FEMS Microbiol Ecol 45, 161-171.

Chróst, R. J. (1991). Environmental control of the synthesis and activity of aquatic microbial ectoenzymes. In Microbial Enzymes in Aquatic Environments, pp. 26-29. Edited by R. J. Chróst. New York: Springer.

de Bruijn, F. J. (1992). Use of repetitive (repetitive extragenic palindromic and enterobacterial repetitve intergenic consensus) sequences and the polymerase chain reaction to fingerprint the genomes of Rhizobium meliloti isolates and other soil bacteria. Appl Environ Microbiol 58, 2180-2187.

de la Torre, J. R., Goebel, B. M., Friedmann, E. I. \& Pace, N. R. (2003). Microbial diversity of cryptoendolithic communities from the McMurdo Dry Valleys, Antarctica. Appl Environ Microbiol 69, 3858-3867.

Denner, E. B. M., Vybiral, D., Kobližek, M., Kämpfer, P., Busse, H.-J. \& Velimirov, B. (2002). Erythrobacter citreus sp. nov., a yellowpigmented bacterium that lacks bacteriochlorophyll $a$, isolated from the western Mediterranean Sea. Int J Syst Evol Microbiol 52, 1655-1661.

Gerhardt, P. (editor) (1994). Methods for General and Molecular Bacteriology. Washington, DC: American Society for Microbiology.

Gich, F., Schubert, K., Bruns, A., Hoffelner, H. \& Overmann, J. (2005). Specific detection, isolation, and characterization of selected, previously uncultured members of the freshwater bacterioplankton community. Appl Environ Microbiol 71, 5908-5919. 
Kolber, Z. S., Van Dover, C. L., Niederman, R. A. \& Falkowski, P. G. (2000). Bacterial photosynthesis in surface water of the open ocean. Nature 407, 177-179.

Kolber, Z. S., Plumley, F. G., Lang, A. S. \& 7 other authors (2001). Contribution of aerobic photoheterotrophic bacteria to the carbon cycle in the ocean. Science 292, 2492-2495.

Kuykendall, L. D., Roy, M. A., O'Neill, J. J. \& Devine, T. E. (1988). Fatty acids, antibiotic resistance, and deoxyribonucleic acid homology groups of Bradyrhizobium japonicum. Int J Syst Bacteriol 38, 358-361.

Labrenz, M., Lawson, P. A., Tindall, B. J., Collins, M. D. \& Hirsch, P. (2005). Roseisalinus antarcticus gen. nov., sp. nov., a novel aerobic bacteriochlorophyll $a$-producing $\alpha$-proteobacterium isolated from hypersaline Ekho Lake, Antarctica. Int J Syst Evol Microbiol 55, 41-47.

Lane, D. J. (1991). 16S/23S rRNA sequencing. In Nucleic Acid Techniques in Bacterial Systematics, pp. 115-175. Edited by E. Stackebrandt \& M. Goodfellow. Chichester: Wiley.

Ludwig, W., Strunk, O., Westram, R. \& 28 other authors (2004). ARB: a software environment for sequence data. Nucleic Acids Res 32, 1363-1371.

Mesbah, M., Premachandran, U. \& Whitman, W. B. (1989). Precise measurement of the $\mathrm{G}+\mathrm{C}$ content of deoxyribonucleic acid by high-performance liquid chromatography. Int J Syst Bacteriol 39, 159-167.

Miller, L. T. (1982). Single derivatization method for routine analysis of bacterial whole-cell fatty acid methyl esters, including hydroxy acids. J Clin Microbiol 16, 584-586.

Miller, T. L. \& Wolin, M. J. (1974). A serum bottle modification of the Hungate technique for cultivating obligate anaerobes. Appl Microbiol 27, 985-987.

Page, K. A., Connon, S. A. \& Giovannoni, S. (2004). Representative freshwater bacterioplankton isolated from Crater Lake, Oregon. Appl Environ Microbiol 70, 6542-6550.

Rainey, F. A., Silva, J., Nobre, M. F., Silva, M. T. \& da Costa, M. S. (2003). Porphyrobacter cryptus sp. nov., a novel slightly thermophilic, aerobic, bacteriochlorophyll a-containing species. Int $J$ Syst Evol Microbiol 53, 35-41.
Rivas, R., Abril, A., Trujillo, M. E. \& Velázquez, E. (2004). Sphingomonas phyllosphaerae sp. nov., from the phyllosphere of Acacia caven in Argentina. Int J Syst Evol Microbiol 54, 2147-2150.

Shiba, T., Shioi, Y., Takamiya, K., Sutton, D. C. \& Wilkinson, C. R. (1991). Distribution and physiology of aerobic bacteria containing bacteriochlorophyll $a$ on the east and west coasts of Australia. Appl Environ Microbiol 57, 295-300.

Stackebrandt, E. \& Goebel, B. M. (1994). Taxonomic note: a place for DNA-DNA reassociation and 16S rRNA sequence analysis in the present species definition in bacteriology. Int J Syst Bacteriol 44, 846-849.

Tindall, B. J. (1990a). A comparative study of the lipid composition of Halobacterium saccharovorum from various sources. Syst Appl Microbiol 13, 128-130.

Tindall, B. J. (1990b). Lipid composition of Halobacterium lacusprofundi. FEMS Microbiol Lett 66, 199-202.

Yoon, J.-H., Kim, H., Kim, I.-G., Kang, K. H. \& Park, Y.-H. (2003). Erythrobacter flavus sp. nov., a slight halophile from the East Sea in Korea. Int J Syst Evol Microbiol 53, 1169-1174.

Yoon, J.-H., Lee, M.-H. \& Oh, T.-K. (2004). Porphyrobacter doghaensis sp. nov., isolated from sea water of the East Sea in Korea. Int J Syst Evol Microbiol 54, 2231-2235.

Yurkov, V. V. (2001). Aerobic phototrophic bacteria. In The Prokaryotes: An Evolving Electronic Resource for the Microbiological Community, 3rd edn, release 3.5, 13 March 2001. Edited by M. Dworkin, S. Falkow, E. Rosenberg, K.-H. Schleifer \& E. Stackebrandt. New York: Springer. http://141.150.157.117:8080/prokPUB/index.htm Yurkov, V. V. \& Beatty, J. T. (1998). Aerobic anoxygenic phototrophic bacteria. Microbiol Mol Biol Rev 62, 695-724.

Yurkov, V. V. \& Gorlenko, V. M. (1990). Erythrobacter sibiricus sp. nov., a new freshwater aerobic bacterial species containing bacteriochlorophyl a. Microbiology (English translation of Mikrobiologiia) 59, 85-89.

Yurkov, V., Stackebrandt, E., Buss, O., Vermeglio, A., Gorlenko, V. \& Beatty, J. T. (1997). Reorganization of the genus Erythromicrobium: description of "Erythromicrobium sibiricum" as Sandaracinobacter sibiricus gen. nov., sp. nov., and of "Erythromicrobium ursincola" as Erythromonas ursincola gen. nov., sp. nov. Int J Syst Bacteriol 47, 1172-1178. 